\title{
FACTORS INFLUENCING OFF-TAKE RATES OF SMALLHOLDER SHEEP FARMING SYSTEMS IN THE WESTERN CAPE PROVINVE OF SOUTH AFRICA
}

\author{
Molotsi, A. H. ${ }^{1}$, Oosting, S. ${ }^{2}$, Cloete, S. W. P. ${ }^{3}$ and Dzama, K. ${ }^{4}$ \\ Correspondence author: A. H. Molotsi. Email: annelind@sun.ac.za
}

\begin{abstract}
The purpose of this study was to determine off-take rates in smallholder sheep farming systems in the Western Cape province of South Africa. A purposeful sampling technique was used where smallholder farmers were selected based on certain criteria. The criterion set out was that farmers must own between five and 100 sheep. Interviews were conducted with 72 smallholder farmers in three districts, namely the West Coast, Karoo and Eden. General information on the socio-economic status of the farmers was obtained through semi-structured questionnaires. The main sources of income for the Karoo farmers was livestock (46\%) and crops for Eden (32\%). Farmers in the West Coast area mostly relied on salaries (43\%), thus off-farm income. The Karoo district sold a higher average number of lambs per year $(41 \pm 8.8)$, with West Coast and Eden selling the same average number of lambs per year at $7 \pm 2.2$ and $7 \pm 2.6$ respectively. Overall, the income derived from livestock is low and not economically sustainable. Therefore, different strategies (such as access to market, financial assistance, improved animal nutrition and health management, as well as sound breeding plans) should be employed to assist smallholder livestock farmers to increase off-take rates.
\end{abstract}

Keywords: Age, District, Gender, Income, Livelihood, Sustainability

\section{INTRODUCTION}

Small stock is mainly kept for socio-economic benefits by poor Southern Africa communities. Such benefits include household food security, capital and direct income (Moyo \& Swanepoel, 2010). Most of the surface area in South Africa is semi-arid which makes it unsuitable for anything but extensive ruminant livestock farming (Cloete \& Olivier, 2010). The ability of sheep to adapt to diverse and often adverse climatic conditions (Rust \& Rust, 2013) ensures that the species plays an important role in resource-poor systems. Few studies in South Africa have described smallholder sheep farming systems in the Western Cape (Grobler, 2010). Previous studies that have been conducted in the Eastern Cape Province and Limpopo have focused on communal farming systems in rural villages, including market access and the economics of smallholder systems (Marais, 2007; Stroebel, Swanepoel \& Pell, 2011). These studies highlighted the difficulty of smallholder farmers to attain market access and improve their livelihoods.

\footnotetext{
${ }^{1}$ Lecturer, Department of Animal Sciences, University of Stellenbosch, Stellenbosch, South Africa, Email: annelind@sun.ac.za

${ }^{2}$ Lecturer, Animal Sciences Group, Animal Production Systems, Wageningen University, Wageningen,

Netherlands, Email: simon.oosting@wurl.nl

${ }^{3}$ Research specialist, Animal Sciences, Western Cape Department of Agriculture, Elsenburg, South Africa, Email: schalkc@elsenburg.com

${ }^{4}$ Professor, Department of Animal Sciences, University of Stellenbosch, Stellenbosch, South Africa, Email: kdzama@sun.ac.za
} 
The introduction of Black Economic Empowerment (BEE) in South Africa after the 1994 election profoundly affected smallholder farmer production. Farming dynamics are different in each province of South Africa and need to be understood before implementing any strategy to improve production (Schwalbach, Groenewald \& Marfo, 2001). Programmes such as the Land Redistribution for Agricultural Development (LRAD) and the Comprehensive Agricultural Support Programme (CASP) have been initiated by the Department of Agriculture to assist in the agricultural development and land restitution of underprivileged communities benefitting from BEE. These initiatives aimed to increase the overall agricultural production in rural areas. Increased agricultural production is expected to improve national and household food security, which is under pressure in Southern Africa (Aliber, 2009). These programmes had some shortcomings and more recent programmes have been introduced as compensation. The Proactive Land Acquisition Strategy (PLAS) is a programme that acquires land for smallholder candidates that have commercial farmers assigned as mentors for the first five years of farming.

Smallholder farmers in South Africa are vulnerable to food insecurity and mostly fall under the poor in the social ranks (Altman, Hart \& Jacobs, 2009; Thamaga-Chitja \& Morojele, 2014). The average monthly income per household is R5615 (Statistics South Africa (StatsSA), 2014) with an average household size of seven members (Mapiye et al, 2009). The role that sheep play to provide food and income is of paramount importance for sustaining the rural livelihood. The off-take of a sheep production system depends on the ewes as the main productive units producing lambs that are sold for generating income. The price for lamb in South Africa in the formal market is currently R74 per $\mathrm{kg}$ for lambs with a medium fat cover on the carcass (Webb, 2015). A carcass weighing 16-20 kg can thus earn up to R1185-R1482 for a resource-poor farmer. Smallholder farmers, however, prefer to sell lambs or adult sheep on the hoof for any price ranging between R863 and R1309 on the informal market (personal communication with smallholder farmers). Commercially, the important factor determining the success of a sheep farmer would be lamb output (numbers or weight marketed) expressed relative to the number of ewes maintained (Cloete et al, 2014). Acceptable performance in an extensive commercial system ranges between 110 and 156\% for lambing percentages (Snyman \& Herselman, 2005) and between 94 and 132\% (Snyman \& Herselman, 2005) for weaning percentage (both expressed over ewes joined).

Smallholder farmers in contrast do not achieve high lambing and weaning percentages due to a number of constraints. These constraints include obsolete management practices, poor environmental conditions resulting from the overexploitation of resources, unstable feed availability, limitations to grazing rights, the adaptability of the breed(s) used, as well as the number of sheep owned by the individual relative to the resources allocated (Mapiye et al, 2009; Rust, Goosen \& Mbatsha, 2015). Grobler (2010) indicated that of the 17 farms benefitting from the LRAD and CASP programmes, only four showed acceptable lamb marketing percentages. Low lamb marketing percentages (defined as lambs sold per ewe mated) resulted from severe drought conditions and lamb losses due to predators. Measuring accurate lambing percentages for smallholder sheep farmers is challenging as these farmers mostly farm extensively and do not keep records. The average number of lambs will thus be used to determine the off-take rate and hence farm productivity. Off-take rate can be defined as the proportion of animals sold or consumed within a year relative to the breeding flock maintained (Otte \& Chilonda, 2002).

A holistic approach is needed to address limitations to production in smallholder sheep farming systems (Kosgey et al, 2008). Therefore, the aim of this study was to determine factors that 
contribute to off-take. The objectives were to describe the socio-economic profile of the farmers in three districts of the Western Cape Province in South Africa, and to investigate which factors significantly influence off-take (average number of lambs sold).

\section{METHODOLOGY}

\subsection{Description of the study site}

The study incorporated three districts in the Western Cape Province, namely the West Coast (Ebenheaser) Municipality in the West Coast, the Central Karoo, and the Eden District (Figure 1). These districts were chosen because they are situated in arid environments according to Köppen -Geiger (Kottek et al, 2006) as sheep are mostly farmed extensively in these areas. The vegetation of the West Coast District is classified under the Succulent Karoo Biome, while the Karoo and Eden are classified as the Nama Karoo Biome (Acocks, 1988). The succulent Karoo mainly consists of succulent plants and is a winter rainfall area. The altitude ranges from sea level to $1500 \mathrm{~m}$ and the mean annual rainfall is between 20 and $350 \mathrm{~mm}$. The Nama Karoo consists mainly of grass-shrub vegetation and ranges from 1000 to $1400 \mathrm{~m}$ in altitude. It is a summer rainfall area and receives 100 to $520 \mathrm{~mm}$ of rain per annum.

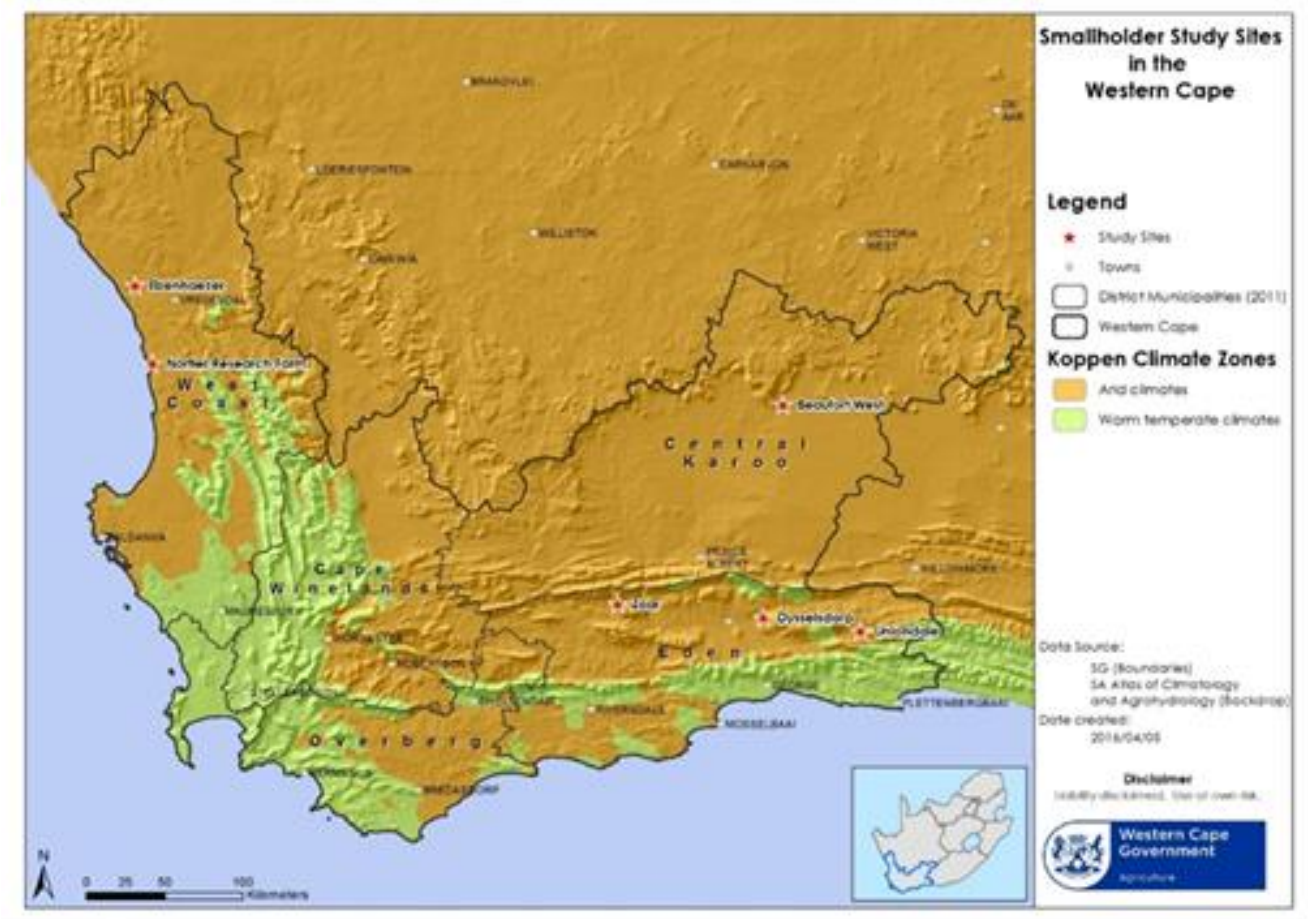

Figure 1: Map of the Western Cape Province in South Africa with the sites where data were obtained from

\subsection{Household surveys}

A purposeful sampling technique was used and farmers were selected based on the number of sheep they kept, which had to be between five and 100 breeding ewes as well as involvement with the government projects of CASP, LRAD and PLAS. Although the focus was mainly on sheep farmers, farmers having both sheep and crops as farming activities were also included to increase the sample size. 
Interviews were conducted with 72 smallholder farmers in total, specifically 21 in the West Coast, 26 in the Central Karoo, and 25 in the Eden District. Information was obtained pertaining to the farming system employed, the number of lambs sold per year as an indication of production performance of the flock, and the number of animal entries and exists per annum during the year the survey was conducted.

\subsection{Statistical analysis}

Descriptive data pertaining to farming systems were analysed using the Statistical Analysis Systems (SAS, 2014) procedures SURVEYMEANS and the SURVEYFREQ. A general linear model (GLM) was conducted using R software (Becker, Chambers \& Wilks, 1988) to determine differences between the three districts regarding the average number of lambs sold per year as well as to fit socio-economic factors as fixed effects in the GLM. The socioeconomic factors fitted were age of the farmer, farm type, sources of income, wealth status, tribe, gender of the household head, whether farmer participated in LRAD, CASP and/or PLAS programme, and flock size. The Bonferroni posthoc test was applied to test for differences between districts for the average number of lambs sold. A GLM was fitted to investigate any differences between districts on lambs born per ewe and lambing percentage, flock size, as well as number of ewes and rams.

\section{RESULTS}

\subsection{Farmers' socio-economic profile}

Livestock production was the major activity for $76 \%$ of the smallholder farmers that completed the survey, while cropping represented $24 \%$. Furthermore, $51 \%$ of the respondents fell within the age range of 40 to 60 years, whereas $20 \%$ were younger than 40 and $29 \%$ were older than 60 years of age (Table 1). The majority of the farmers $(67 \%)$ ranked themselves as having a medium wealth status, while $32 \%$ ranked themselves as poor. The households interviewed were male dominated with $90 \%$ of the respondents being male and only $10 \%$ female. Land ownership was categorised as 36\% self-owned, $29 \%$ leased, and $29 \%$ communal land. The remaining $6 \%$ of the farmers preferred not to disclose information on their land ownership.

Table 1: Socio-economic description of farmers in the Western Cape Province

\begin{tabular}{|l|l|}
\hline Socio-economic profiles & \multicolumn{1}{c|}{ Proportions } \\
\hline \multicolumn{2}{c|}{ Age } \\
\hline$<40$ years & $20 \%$ \\
\hline $40-60$ years & $51 \%$ \\
\hline$>60$ years & $29 \%$ \\
\hline \multicolumn{2}{c|}{ Gender } \\
\hline Male & $90 \%$ \\
\hline Female & $10 \%$ \\
\hline \multicolumn{2}{|c|}{ Wealth status } \\
\hline Poor & $32 \%$ \\
\hline Medium & $67 \%$ \\
\hline Rich & \\
\hline \multicolumn{2}{c}{} \\
\hline
\end{tabular}




\begin{tabular}{|l|l|}
\hline Self-owned & $36 \%$ \\
\hline Leased & $29 \%$ \\
\hline Communal & $29 \%$ \\
\hline Undisclosed & $6 \%$ \\
\hline
\end{tabular}

Table 2 displays the sale outlets of smallholder farmers per district. Outlets for the Eden District included home consumption and private sales during holiday seasons such as Easter and Christmas. The activity of farmers in Eden was focused on crop production, which was also their main source of income. Farmers in the Karoo district were actively involved in a LRAD project. It was evident that these farmers choose to supply meat to the formal market. Farmers in the West Coast District sold sheep to the informal market and the money so obtained was used for subsistence and emergency cash. Based on the sale outlet, the different districts can be classified as either being market orientated or subsistence orientated. Thus, Eden and West Coast can be considered more subsistence orientated, while the Karoo District is more commercially orientated.

Table 2: Description of the farming systems and sale outlets per district in the Western Cape Province

\begin{tabular}{|c|c|c|c|}
\hline Farming system & District & $\begin{array}{l}\text { Sources of } \\
\text { income }\end{array}$ & $\begin{array}{l}\text { Sale outlet for } \\
\text { livestock }\end{array}$ \\
\hline \multirow{6}{*}{$\begin{array}{l}\text { Both communal and small-scale } \\
\text { (subsistence orientated) }\end{array}$} & \multirow[t]{6}{*}{ Eden } & Crops $(32 \%)$ & \multirow{6}{*}{$\begin{array}{l}\text { Home consumption and } \\
\text { private sales }\end{array}$} \\
\hline & & Grants $(20 \%)$ & \\
\hline & & $\begin{array}{l}\text { Livestock } \\
(16 \%)\end{array}$ & \\
\hline & & Salaries $(16 \%)$ & \\
\hline & & Other $(12 \%)$ & \\
\hline & & $\begin{array}{l}\text { No indication } \\
(4 \%)\end{array}$ & \\
\hline \multirow[t]{5}{*}{$\begin{array}{l}\text { Communal, small-scale and large- } \\
\text { scale (market orientated) }\end{array}$} & \multirow[t]{5}{*}{ Karoo } & $\begin{array}{l}\text { Livestock } \\
(46 \%)\end{array}$ & \multirow[t]{5}{*}{ Abattoir } \\
\hline & & Salaries $(23 \%)$ & \\
\hline & & $\begin{array}{l}\text { Home } \\
\text { industries } \\
(15 \%)\end{array}$ & \\
\hline & & Crops (12\%) & \\
\hline & & Grants (4\%) & \\
\hline \multirow{4}{*}{$\begin{array}{l}\text { Communal and small-scale } \\
\text { (subsistence orientated) }\end{array}$} & \multirow[t]{4}{*}{ West Coast } & Salary $(43 \%)$ & \multirow[t]{4}{*}{ Private sales } \\
\hline & & Grants $(29 \%)$ & \\
\hline & & Crops $(14 \%)$ & \\
\hline & & $\begin{array}{l}\text { Not indicated } \\
(14 \%)\end{array}$ & \\
\hline
\end{tabular}

\subsection{Average number of lambs sold (off-take)}

The fixed effects fitted for the respective socio-economic factors, age of the farmer, farm type, sources of income, wealth status, tribe, gender of household head, whether or not farmers 
participated in LRAD, CASP and/or PLAS programmes, and flock size were insignificant. Therefore, only district is discussed as a factor that influences the average number of lambs sold (off-take). Significant differences were only obtained between districts for average number of lambs sold. The results in Table 3 suggest that smallholder farmers from the Karoo district sold a higher absolute number of lambs per year $(41 \pm 8.8)$, with West Coast and Eden selling the same average number of lambs per year at $7 \pm 2.2$ and $7 \pm 2.6$ respectively. Lambs born per ewe (as recorded from the surveys based on interviews with individual respondents) were used to calculate average lambing percentages $( \pm \mathrm{SE})$ per district. Lambing percentages averaged $139 \pm 38 \%$ for the Eden District, $83 \pm 15 \%$ for the Karoo District, and $61 \pm 12 \%$ for the West Coast District.

Table 3: Least square means $( \pm \mathrm{SE})$ obtained from the GLM analysis depicting the measures of lamb output per household in the three districts

\begin{tabular}{|l|l|l|l|l|l|l|}
\hline District & $\begin{array}{l}\text { Average } \\
\text { number of } \\
\text { lambs sold per } \\
\text { breeding } \\
\text { season/year } \\
( \pm \text { SE) }\end{array}$ & $\begin{array}{l}\text { Total } \\
\text { flock size } \\
( \pm \text { SE) }\end{array}$ & $\begin{array}{l}\text { Ewes } \\
( \pm \text { SE })\end{array}$ & $\begin{array}{l}\text { Rams } \\
( \pm \text { SE })\end{array}$ & $\begin{array}{l}\text { Lambs } \\
\text { born per } \\
\text { breeding } \\
\text { season } \\
( \pm \text { SE })\end{array}$ & $\begin{array}{l}\text { Lambing } \\
\text { percentage } \\
( \pm \text { SE })\end{array}$ \\
\hline Eden & $7 \pm 2.6^{\mathrm{b}}$ & $45 \pm 11^{\mathrm{b}}$ & $32 \pm 9.3^{\mathrm{b}}$ & $\begin{array}{l}1.2 \pm \\
0.26^{\mathrm{a}}\end{array}$ & $26 \pm 6.1^{\mathrm{b}}$ & $\begin{array}{l}139 \pm \\
38^{\mathrm{b}} \%\end{array}$ \\
\hline Karoo & $41 \pm 8.8^{\mathrm{a}}$ & $256 \pm 61^{\mathrm{c}}$ & $184 \pm 45^{\mathrm{c}}$ & $\begin{array}{l}6.5 \pm \\
1.2^{\mathrm{b}}\end{array}$ & $\begin{array}{l}105 \pm \\
20^{\mathrm{c}}\end{array}$ & $83 \pm 15^{\mathrm{a}} \%$ \\
\hline West Coast & $7 \pm 2.2^{\mathrm{b}}$ & $23 \pm 2.5^{\mathrm{a}}$ & $16 \pm 2.5^{\mathrm{a}}$ & $\begin{array}{l}1.3 \pm \\
0.16^{\mathrm{a}}\end{array}$ & $12 \pm 2.1^{\mathrm{a}}$ & $61 \pm 12^{\mathrm{a}} \%$ \\
\hline
\end{tabular}

Note: ${ }^{\mathrm{a}-\mathrm{b}}=\mathrm{P}<0.05$; means in rows differ significantly from one another; results from post-hoc bonferroni test.

\section{DISCUSSION}

This study provides insights into the socio-economic profile of smallholder sheep farmers in South Africa and its influence on the average number of lambs sold. Most of the smallholder farmers fell within the age range of 40 to 60 years. This concurs with literature that the smallholder farmers in South Africa are mostly above the age of 40 (Marandure et al, 2016; Motiang \& Webb, 2016). It could be due to the effects of migration of young rural residents to urban areas in search of better working and living conditions (Dossa et al, 2008). In addition, the rural youth are generally not interested in agriculture as a career. Sheep farming was dominated by males in this study, a result corresponding to other studies where males are more likely to farm with sheep and females with goats (Dossa et al, 2008).

Farmers in the West Coast were more likely to sell their products to the informal market. These farmers have indicated that the price received per lamb was better when sold privately compared to marketing lambs at the local abattoir (personal communication). This could be due to the market costs levied in the formal market if a farmer does not sell a high number of lambs at any given time as well as transport costs. The Karoo farmers were also described as being more market orientated and selling their products to the abattoir. Sources of income also varied with district, with the West Coast participants receiving most of their income from salaries and grants, while Eden participants received income from crops and grants. This outcome can partly be explained by the reasons for keeping sheep, as some farmers indicated 
that they kept sheep for a hobby or cultural reasons, thus, not necessarily to obtain income. This concurs with the study of Motiang and Webb (2016) who indicated that $55 \%$ of households relied on income from livestock and $47 \%$ from social grants. Farmers in the Mopeane-Rustenburg area also derived most of their income from off-farm sources of income (Schwalbach et al, 2001). These farmers were only farming as a part-time activity, a scenario which was also observed in the West Coast where communal farming has been practiced for many generations.

The assumption that the West Coast district was mainly subsistence orientated and the Karoo being more market-orientated was confirmed by the results of this study. The different districts can be associated with different farming systems when considering the different sale outlets and sources of income. Although the Karoo farmers were more market orientated in their sale outlets and achieved the highest absolute number of lambs sold, they achieved lower lambing percentages than Eden and higher lambing percentages than the West Coast. This could be due to their recent inclusion in the PLAS programme and the need to grow their ewe flocks. The previous contention that livestock did not contribute to the income of smallholder farmers in the West Coast District does not seem to be borne out by these results. This contradiction could be related to the $14 \%$ of respondents who did not disclose their main source of income.

Converting the average number of lambs sold to monetary terms, assuming that the price per $\mathrm{kg}$ per lamb is R74 per kg with an average carcass weight of $20 \mathrm{~kg}$, and then the income per farming unit in each district will be R60 680 for the Karoo and R10 360 for both the West Coast and Eden Districts per annum. Considering the costs involved in any farming operation, these values are low and would not be able to sustain the livelihood of the farmers involved on their own. These income values amount to R863 per month for the West Coast and Eden Districts, which is below the R4028 minimum wage requirement and R5056 per month for the Karoo District, which is just R1028 above the minimum wage. Another study showed that the annual income for smallholder farmers in Mopeane-Rustenburg amounted to R1079-R2143 per month for $42 \%$ of the respondents interviewed (Schwalbach et al, 2001). These values were below the monthly income from livestock for smallholder farmers in the Karoo and higher than the income of smallholder farmers in both the West Coast and Eden. The majority of South Africans' monthly expenditure was between R2690 and R5380 in 2014 (StatsSA, 2014). The income of smallholder farmers derived from livestock is therefore below the amount needed for monthly sustenance. This situation is economically unsustainable, as the farmers' livelihood cannot be solely secured by income from livestock.

\section{CONCLUSION AND RECOMMENDATIONS}

The mean age of smallholder sheep farmers is a cause for concern as most farmers are above the age where farming is recommended as an occupation. This leaves the question of how sheep farming will be sustained in the long term and how to re-engage the interest of the youth in sheep farming. The percentage of farmers indicating their wealth status as poor is also of concern for the livelihood of these farmers and the long-term sustainability of smallholder sheep production in the Western Cape Province of South Africa. The income derived from livestock (calculated by the average number of lambs sold) is low and not economically sustainable. There is potential for income derived from livestock to increase if the average number of lambs sold can be increased, as seen in Karoo farmers. However, for income to be at a sustainable level, husbandry aspects (such as improved animal nutrition and health management, as well as sound breeding plans) should be addressed, as well as other socio- 
economic and political issues. Addressing issues such as age, gender imbalances, and land ownership could have a positive influence on the overall sustainability of sheep farming systems in the Western Cape Province. The latter issues can be addressed by increasing awareness to the youth and women about career opportunities in animal husbandry. Practically, this implies that agricultural extension, public, private, and higher education institutions should be involved in the creation of more platforms for training and education of youth and females in the field of agriculture. Training of farmers on implementing husbandry practices that can assist in improved off-take rates should be provided; this should include the encouragement of record keeping of management practices employed by smallholder sheep farmers. This is a complex issue and will need innovation and collaboration in terms of how to make sheep husbandry a promising and sustainable option for the future.

\section{REFERENCES}

ACOCKS, J.P., 1988. Veld type of South Africa. In: Memoirs of the botanical survey of South Africa (pp.123). Pretoria: Government Printer.

ALIBER, M., 2009. Exploring statistics South Africa's national household surveys as sources of information about household-level food security. Agrekon, 48(4):384-409.

ALTMAN, M., HART, T.G. \& JACOBS, P.T., 2009. Household food security status in South Africa. Agrekon, 48(4):345-361.

BECKER, R.A., CHAMBERS, J.M. \& WILKS, A.R., 1988. The new S language. New York: Chapman \& Hall.

CLOETE, S.W.P. \& OLIVIER, J.J., 2010. South African sheep and wool industries. In The international sheep and wool handbook (pp.95-104). Nottingham: Nottingham University Press.

CLOETE, S.W.P., OLIVIER, J.J., SANDENBERGH, L. \& SNYMAN, M.A., 2014. The adaption of the South Africa sheep industry to new trends in animal breeding and genetics: A review. S. Afr. J. Anim. Sci., 44(4):307-321.

DOSSA, L.H., RISCHKOWSKY, B., BIRNER, R. \& WOLLNY, C., 2008. Socio-economic determinants of keeping goats and sheep by rural people in Southern Benin. Agric. Human Values, 25(4):581-592.

GROBLER, H.J.F., 2010. Evaluation survey at extensive farms in the Central Karoo 2009. Agriprobe, 7(2):6-9.

KOSGEY, I.S., ROWLANDS, G.J., VAN ARENDONK, J.A.M. \& BAKER, R.L., 2008. Small ruminant production in smallholder and pastoral/extensive farming systems in Kenya. Small Rumin. Res., 77(1):11-24.

KOTTEK, M., GRIESER, J., BECK, C., RUDOLF, B. \& RUBEL, F., 2006. World map of the Köppen-Geiger climate classification updated. Meteorol. Z., 15(3):259-263.

MAPIYE, C., CHIMONYO, M., DZAMA, K., RAATS, J.G. \& MAPEKULA, M., 2009. Opportunities for improving Nguni cattle production in smallholder farming systems of South Africa. Livest. Sci., 124(1-3):196-204.

MARAIS, P.G., 2007. Evaluation of the genetic potential for growth and wool production of typical Transkei ewes and rams. Grootfontein Agricultural Development Institute Research Report. Middelburg, South Africa. 
MARANDURE, T., MAPIYE, C., MAKOMBE, G. \& DZAMA, K., 2016. Indicator-based sustainability assessment of the smallholder beef cattle production in South Africa. Agroecol. Sust. Food Syst., 41(1):3-29.

MOTIANG, D.M. \& WEBB, E.C., 2016. The influence of household characteristics on cattle off-take rates in the North West Province of South Africa. Livestock Res. Rural Devel., 28(6):1-9.

MOYO, S. \& SWANEPOEL, F.J.C., 2010. Multifunctionality of livestock in developing communities. In The role of livestock in developing communities: Enhancing multifunctionality (pp.1-12). Bloemfontein: University of the Free State.

OTTE, M.J. \& CHILONDA, P., 2002. Cattle and small ruminant production systems in SubSaharan Africa. A systematic review. Rome: Food and Agriculture Organization.

RUST, J.M. \& RUST, T., 2013. Climate change and livestock production: A review with emphasis on Africa. S. Afr. J. Anim. Sci., 43(3):255-267.

RUST, T., GOOSEN, W.J. \& MBATSHA, Z., 2015. Characterization of production outputs and ewe flock structure of communal wool sheep in Ngqolowa, Eastern Cape. Appl. Anim. Husb. Rural Develop., 8(1):6-18.

SCHWALBACH, L.M., GROENEWALD, I.B. \& MARFO, C.B., 2001. A survey of smallscale cattle farming systems in the North West Province of South Africa. S. Afr. J. Anim. Sci., 31(3):200-204.

SNYMAN, M.A. \& HERSELMAN, M.J., 2005. Comparison of productive and reproductive performance efficiency of Afrino, Dorper and Merino sheep in the False Upper Karoo. S. Afr. J. Anim. Sci., 35(2):98-108.

STATSITICAL ANALYSIS SYSTEMS (SAS), 2014. SAS Institute. North Carolina: Cary.

STATISTICS SOUTH AFRICA (StatsSA), 2014. General household survey, 2013. Available from: www.statssa.gov.za/publications/P0318/P03182013.pdf

STROEBEL, A., SWANEPOEL, F.J.C. \& PELL, A.N., 2011. Sustainable smallholder livestock systems: A case study of Limpopo Province, South Africa. Livest. Sci., 139(12):186-190.

THAMAGA-CHITJA, J.M. \& MOROJELE, P., 2014. The context of smallholder farming in South Africa: Towards a livelihood asset building framework. J. Hum. Ecol., 45(2):147155.

WEBB, E.C., 2015. Description of carcass classification goals and the current situation in South Africa. S. Afr. J. Anim. Sci., 45(3):229-233. 
